\title{
Processing, physicochemical, and sensory analyses of ostrich meat hamburger
}

\author{
Processamento, análise físico-química e sensorial do hambúrguer de carne de avestruz
}

\author{
Vera Lúcia Ferreira de SOUZA ${ }^{1 *}$, Jaqueline Yumi SASAKI ${ }^{2}$, Maria Luiza Rodrigues de Souza FRANCO ${ }^{1}$, \\ Maria José Baptista BARBOSA ${ }^{3}$, Rejane Machado CARDOZO 3
}

\begin{abstract}
The objective of this study was to assess the potential utilization of ostrich meat trimming in hamburger preparation, as well as its physicochemical and sensory characterization. Using ostrich meat trimmings from the legs and neck, four different formulations were prepared with varied amounts of bacon and textured soybean protein. Physical analysis of yield, shrinkage percentage, and water retention capacity and chemical analysis of proximate composition, cholesterol levels, and calories were performed. The formulations underwent sensory analysis by 52 potential ostrich meat consumers, who evaluated tenderness, juiciness, flavor, and purchase intent. The formulations containing textured soybean protein showed the highest yield, lowest shrinkage percentage, and highest water retention capacity. Lipid content varied from 0.58 to $4.99 \%$; protein from 17.08 to $21.37 \%$; ash from 3.00 to $3.62 \%$; moisture from 73.87 to $76.27 \%$; cholesterol from 22.54 to $32.11 \mathrm{mg} .100$ g-1; and calorie from 87.22 to $163.42 \mathrm{kcal} .100 \mathrm{~g}^{-1}$. All formulations showed low cholesterol and calorie levels, even that containing $10 \%$ bacon and $3.5 \%$ textured soybean protein, which achieved the best scores and acceptance by the panelists.
\end{abstract}

Keywords: bacon; calories; cholesterol; lipids; textured soybean protein; sensory analysis.

\section{Resumo}

O objetivo deste trabalho foi verificar a potencialidade do aproveitamento tecnológico de aparas da carne de avestruz na elaboração de hambúrguer, e sua caracterização físico-química e sensorial. Com aparas de carne de avestruz, retiradas das pernas e pescoço, foram elaboradas quatro diferentes formulações de hambúrgueres, variando teores de toucinho e proteína texturizada de soja. Foram feitas análises físicas de rendimento, percentagem de encolhimento e capacidade de retenção de água; e análises químicas de composição centesimal, teores de colesterol e calorias. As formulações foram analisadas através de teste afetivo por 52 potenciais consumidores de carne de avestruz, que avaliaram a maciez, suculência, sabor e intenção de compra. As formulações com proteína texturizada de soja apresentaram o maior rendimento, menor percentagem de encolhimento e maior capacidade de retenção de água. Os teores de lipídios variaram de 0,58 a 4,99\%; proteína de 17,08 a 21,37\%; cinzas de 3,00 a 3,62\%; umidade de 73,87 a 76,27\%; colesterol de 22,54\% a 32,11 mg. $100 \mathrm{~g} \mathrm{~g}^{-1}$; e calorias de 87,22\% a $163,42 \mathrm{kcal} .100 \mathrm{~g}{ }^{-1}$. Todas as formulações apresentaram baixos teores de colesterol e calorias, mesmo o hambúrguer feito com 10\% de toucinho e 3,5\% de proteína texturizada de soja, que obteve as melhores notas e aceitação pelos painelistas.

Palavras-chave: toucinho; calorias; colesterol; lipídios; proteína texturizada de soja; avaliação sensorial.

\section{Introduction}

Among the most appreciated red meats, in addition to beef and horse meat, is ostrich meat. Ostrich belongs to the class Aves, subclass Neornithes, superorder Paleognathae, order Struthioniformes, suborder Struthiones, family Struthionidae, genus Struhio, and species Struthio camelus. Ostriches are large birds of approximately 2.15 to $2.45 \mathrm{~m}$ in height and weigh up to $160 \mathrm{~kg}$. Their slaughter weight (12 to 14 months of age) is approximately 105 to $120 \mathrm{~kg}$. This bird is native to South Africa, which has the world's largest ostrich breeding stock, estimated at 150 thousand birds per year. Ostrich is also raised in European countries such as Belgium, Holland, France, and Italy (FALVELA, 2004).
The commercial production of ratites (ostrich) in Brazil started in 1994, and has shown great adaptability to withstand high and low temperatures (LUCHINI; COSTA, 1998).

Ostriches have an estimated reproductive life of 35 to 40 years and average life expectancy of 70 to 80 years. Sexual maturity occurs at 30 months of age for males and 20 months for females. Annual egg production is between 30 to 50 eggs, and the incubation period lasts for 42 days. There are three commercial breeds corresponding to the following subspecies: "African black" (Struthio camelus domesticus), with gray-colored neck; "Blue neck" (Struthio camelus australis); and "Red neck" (Struthio camelus massaicus) (FALVELA, 2004).

\footnotetext{
Received 30/6/2010

Accepted 23/2/2012 (004903)

${ }^{1}$ Departamento de Zootecnia, Centro de Ciências Agrárias, Universidade Estadual de Maringá - UEM, Av. Colombo, 5790, Bl. J45, CEP 87020-900, Maringá, PR, Brasil, e-mail:vlfsouza@uem.br;mlrsouza@uem.br

${ }^{2}$ Departamento de Engenharia Química, Centro de Tecnologia, Universidade Estadual de Maringá - UEM, Av. Colombo, 5790, Bl. 09, CEP 87020-900, Maringá, PR, Brasil, e-mail: jaqueline_sasaki@hotmail.com

3 Departmento de Medicina Veterinária, Centro de Ciências Agrárias, Universidade Estadual de Maringá - UEM, Estrada da Paca, s/n, São Cristovão, CP 65, CEP 87507-190, Umuarama, PR, Brasil,e-mail:mjbbarbosa@uem.br; rmcardozo@uem.br

${ }^{*}$ Corresponding author
}

DOI: http://dx.doi.org/10.1590/S0101-20612012005000062 
Ostriches can provide several commercially attractive products including meat, eggs for initial farming, strong leather, and feathers. Brazil is one of the largest consumers of ostrich feather for the carnival costume industry and brushes for industrial use (LUCHINNI; COSTA, 1998).

According to Falvela (2004), ostrich meat is rich in polyunsaturated fatty acids and has low levels of saturated fat and sodium, which makes it a healthy alternative to other red meats. Although ostrich meat in natura can already be found in the domestic market, production of meat trim products is still quite incipient.

One of these products is the hamburger patty, which is defined as an industrialized meat product obtained from ground meat, with or without added fat tissue and ingredients, molded and subjected to an adequate technological process, featuring the characteristic hamburger texture, color, taste, and odor (BRASIL, 2006).

The increasing rapid pace of lifestyle worldwide has led to the development of a new market sector devoted to easy-tomake food. Accordingly, hamburgers are an excellent option and have become the main product commercialized by fastfood chains.

Therefore, this work aimed to assess the potential utilization of ostrich meat in hamburger patty production using secondary meat cuts such as trimmings removed from bones during deboning. The characterization was made by physicochemical analyses, and acceptability was investigated by sensory analysis to check whether ostrich meat could become an option for hamburger production.

\section{Materials and methods}

The experiment was performed at the Food Engineering laboratory of the Chemical Engineering department at the State University of Maringá.

\subsection{Raw materials}

The meat for hamburger production was obtained from African black ostriches (COPATRUZ in Apucarana/PR), selected under optimal health and hygiene conditions, aged between 12 and 14 months weighing approximately $110 \mathrm{~kg}$. The birds were slaughtered at the City Cattle Abattoir of Apucarana/PR, and after deboning, the meat trimmings from the legs and neck were selected.

\subsection{Hamburger production}

In order to produce hamburger patties, after discarding conjunctive tissue and fat, the meat was ground using a PJ10JAMAR grinder with a $5 \mathrm{~mm}$ disc, packed in plastic bags properly identified, and frozen at $-18^{\circ} \mathrm{C}$. The meat was thawed slowly at $5{ }^{\circ} \mathrm{C}$ for 24 hours. The treatments were then devised based on the components (Table 1), according to Brasil (2006).

The amounts of bacon added in the hamburgers were $0 \%$ and $10 \%$ wet base (w.b.), whereas the amounts of textured soybean protein (TSP) added were $0 \%$ and $3.5 \%$ (w.b.) (Table 2).
Table 1. Composition wet base of burger patties made from Ostrich meat.

\begin{tabular}{ll}
\hline Description of raw materials & Quantity $(\%)$ \\
\hline Ostrich Meat & 62.9 to 97.9 \\
Pepper & 0.1 \\
Salt & 2.0 \\
TSP $^{1}$ & 0 to 15 \\
Bacon & 0 to 10 \\
Total & 100.0 \\
\hline
\end{tabular}

${ }^{1}$ Textured soybean protein.

Table 2. Variation in bacon and textured soybean protein (TSP) levels wet base by treatment.

\begin{tabular}{ccc}
\hline Treatment & Bacon $(\%)$ & TSP (\%) \\
\hline 1 & 0 & 0 \\
2 & 0 & 3.5 \\
3 & 10 & 0 \\
4 & 10 & 3.5 \\
\hline
\end{tabular}

Bacon was ground prior to preparing the hamburgers, and $250 \mathrm{~g}$ of TSP were added to $1 \mathrm{~L}$ of boiling water. The TSP was left in water for 2 hours and then submitted to pressure in order to remove excess water (FERNÁNDEZ-LOPEZ et al., 2006).

The meat was mixed in with the ingredients using a MJ35JAMAR blender, and the patties were molded and pressed using an $11 \mathrm{~cm}$ hamburger maker resulting in a total of 60 hamburger patties, $60 \mathrm{~g}$ each. Next, the patties were conditioned individually in plastic bags, identified by treatment, and kept frozen at $-18^{\circ} \mathrm{C}$ in a freezer until sensory and physicochemical analyses.

\subsection{Sensory analysis}

The formulations underwent sensory analysis by 52 potential ostrich meat consumers, who evaluated tenderness, juiciness, flavor, and purchase intent (ANZALDÚA-MORALEZ, 1994).

Each potential consumer was given $1 / 4$ grilled hamburgers (approximately $10 \mathrm{~g}$ ) from each treatment in plastic plates, followed by a glass of water and a cream cracker. The hamburger samples were served after being grilled whole at $150{ }^{\circ} \mathrm{C}$ for 6 minutes. The plastic plates were coded with random threedigit numbers.

The project of which this study is part was approved by the Permanent Committee for Research with Human Beings (COPEP/CAAE 045.0.093.000-09/OPINION 090-2009) at the State University of Maringá/PR, and all participants signed a consent form, according to the norms of CNS/MS Resolution 196/96 (BRASIL, 1996).

\subsection{Physical analysis}

\section{Cooking yield}

Hamburger yield was calculated by the difference between the raw and cooked weight of each sample, according to Berry apud Seabra et al. (2002) (Equation 1). 
$\%$ Yield $=\frac{\text { Cooked sample weight }}{\text { Raw sampleweight }} \times 100$

\section{Shrinkage from cooking}

The shrinkage percentage of the patties was calculated according to Berry apud Seabra et al. (2002) (Equation 2).

$\%$ Shrinkage $=\frac{\text { raw sample diameter }- \text { cooked diameter }}{\text { raw sample diameter }} \times 100$

\section{Water retention capacity (WRC)}

The water retention capacity (WRC) percentage was calculated according to Seabra et al. (2002) (Equation 3).

$\% W R C=1-\frac{A-D}{U} \times 100$

Where: $\mathrm{A}=$ Sample weight $(\mathrm{g})$ prior to heating; $\mathrm{D}=$ Sample weight (g) after heating and centrifuging; $U$ = Total water in the sample (\%), based on the moisture level in the patty

\subsection{Chemical analysis}

Chemical analyses were performed at the Food Analysis Laboratory of the Food Science and Technology Department, at the Agrarian Sciences Center of the State University of Londrina. The analyses were done on the raw products, in triplicate.

\section{Sample preparation}

Three hamburgers were selected at random from each formulation and cut into small pieces. Each sample was homogenized using an electric meat grinder with $5 \mathrm{~mm}$ discs, placed in hermetically sealed containers, and kept frozen at $-18^{\circ} \mathrm{C}$ until analysis.

\section{Analyses of proximate composition, carbohydrates, cholesterol and calories}

Lipid levels of the patties was determined by gravimetry according to Folch, Less and Stanley (1957). Moisture, ash, and calories were determined according to Association of Official and Agricultural Chemistry (1999), and the cholesterol levels were determined according to Baggio and Bragagnolo (2000).

\subsection{Statistical analysis}

The experimental design was entirely randomized, and the data obtained in the physicochemical and sensory analysis of the four hamburger formulations were analyzed by analysis of variance (ANOVA) and Tukey's test to compare the averages among the samples at a 5\% significance level. Statistical Analisys System Institute software (1999) was used for data analysis.

\section{Results and discussion}

The analysis of the results for the attributes tenderness, juiciness, flavor, and purchase intent of the hamburger samples with different formulations is expressed on Table 3.
Table 3. Mean values and standard deviation of the quality attributes of samples of ostrich meat burger patties.

\begin{tabular}{ccccc}
\hline Treatment & Juiciness & Flavor & Tenderness & $\begin{array}{c}\text { Purchasing } \\
\text { intention }\end{array}$ \\
\hline 1 & $6.2 \pm 1.8^{\mathrm{c}}$ & $6.3 \pm 1.6^{\mathrm{c}}$ & $6.3 \pm 1.7^{\mathrm{c}}$ & $4.0 \pm 1.2^{\mathrm{b}}$ \\
2 & $6.9 \pm 1.4^{\mathrm{b}}$ & $6.9 \pm 1.5^{\mathrm{b}}$ & $6.5 \pm 1.4^{\mathrm{c}}$ & $4.4 \pm 1.0^{\mathrm{a}}$ \\
3 & $7.0 \pm 1.5^{\mathrm{b}}$ & $7.1 \pm 1.4^{\mathrm{b}}$ & $6.9 \pm 1.5^{\mathrm{b}}$ & $4.7 \pm 1.1^{\mathrm{a}}$ \\
4 & $7.4 \pm 1.3^{\mathrm{a}}$ & $7.5 \pm 1.1^{\mathrm{a}}$ & $7.3 \pm 1.1^{\mathrm{a}}$ & $4.9 \pm 0.9^{\mathrm{a}}$ \\
\hline
\end{tabular}

Means in the same column, followed by different lowercase letters, are significantly different $(\mathrm{p}<0.05)$ by Tukey's test. Treatment $1=0 \%$ bacon and $0 \%$ Textured Soybean Protein (TSP); Treatment $2=0 \%$ bacon and 3.5\% TSP; Treatment $3=10 \%$ bacon and $0 \%$ TSP; Treatment $4=10 \%$ bacon and $3.5 \%$ TSP.

Treatment 4, which has the highest content of bacon and TSP, showed the highest scores for the attributes juiciness, flavor, and tenderness, differing significantly $(\mathrm{p}<0.5)$ from the others. According to Sá (2004), juiciness depends on water retention capacity and fat level, which also provides better flavor and tenderness. The flavor score for treatment 4 is close to that observed by Hautrive et al. (2008), who obtained a 7.24 average for the flavor of ostrich meat hamburgers.

With regard to purchase intent, no significant difference was observed between treatments 2, 3, and 4, and treatment 1 showed the lowest average $(\mathrm{p}<0.05)$. Even so, all treatments showed an average close to "certainly would buy". Hautrive et al. (2008), comparing ostrich, beef, and mixed hamburgers, observed the highest averages for purchase intent for those made from ostrich meat.

The formulations with 3.5\% TSP showed the best yield, the lowest shrinkage during cooking, and the highest water retention capacity.

The highest yield averages are close to those observed by Hautrive et al.(2008), in ostrich meat hamburgers (77.5\%). On the other hand, Hautrive et al.(2008) observed 98.0\% averages for water retention capacity, which were much higher than those found in the different studied treatments (Table 4).

Seabra et al. (2002), studying meat burgers with added cassava starch, observed averages of $73.78 \%$ for WRC and $15.47 \%$ for cooking shrinkage, values which are quite close to those observed in treatments 2 and 4 (Table 4).

The averages observed for protein, ash, and moisture levels did not show significant differences (Table 5). Hautrive et al. (2008) observed average protein levels of 19.74 and 76.26 (\%) for moisture in ostrich meat hamburgers, values which are quite close to those observed in the present study. On the other hand, Tavares et al. (2007) observed an average of $68.34 \%$ moisture in hamburger patties made from rabbit meat, a value which is lower than those observed in the four treatments.

With regard to ash levels, the observed average was higher than those reported by Hoffman and Fisher (2001), 1.20\%, and Bani et al. (2007), 1.08\%. In both cited studies, which investigated $100 \%$ pure ostrich meat, unlike hamburger patties, which are added with seasonings that increase ash levels. 
Table 4. Mean values and standard deviation of the physical characteristics of samples of ostrich meat burger patties.

\begin{tabular}{cccc}
\hline Treatment & Yield (\%) & Shrinkage (\%) & $\begin{array}{c}\text { Water retention } \\
\text { capacity (\%) }\end{array}$ \\
\hline 1 & $70.3 \pm 2.8^{\mathrm{b}}$ & $23.5 \pm 2.6^{\mathrm{a}}$ & $71.5 \pm 2.7^{\mathrm{b}}$ \\
2 & $78.3 \pm 1.9^{\mathrm{a}}$ & $16.6 \pm 2.5^{\mathrm{b}}$ & $77.7 \pm 2.4^{\mathrm{a}}$ \\
3 & $71.5 \pm 2.5^{\mathrm{b}}$ & $21.6 \pm 1.9^{\mathrm{a}}$ & $72.2 \pm 1.9^{\mathrm{b}}$ \\
4 & $77.9 \pm 2.3^{\mathrm{a}}$ & $15.3 \pm 2.1^{\mathrm{b}}$ & $78.2 \pm 2.1^{\mathrm{a}}$ \\
\hline
\end{tabular}

Means in the same column, followed by different lowercase letters, are significantly different $(\mathrm{p}<0.05)$ by Tukey's test. Treatment $1=0 \%$ bacon and $0 \%$ Textured Soybean Protein (TSP); Treatment $2=0 \%$ bacon and 3.5\% TSP; Treatment $3=10 \%$ bacon and $0 \%$ TSP; Treatment $4=10 \%$ bacon and $3.5 \%$ TSP.

Table 5. Proximate composition wet base of ostrich burger.

\begin{tabular}{lrrrrr}
\hline \multicolumn{1}{c}{ Treatments } & 1 & 2 & 3 & 4 & $\begin{array}{r}\text { CV } \\
(\%)\end{array}$ \\
\hline Lipids (\%) & $1.7^{\mathrm{b}}$ & $1.6^{\mathrm{b}}$ & $4.9^{\mathrm{a}}$ & $3.9^{\mathrm{a}}$ & 10.1 \\
Protein (\%) & $19.0^{\mathrm{a}}$ & $20.4^{\mathrm{a}}$ & $18.1^{\mathrm{a}}$ & $18.5^{\mathrm{a}}$ & 12.4 \\
Ash (\%) & $3.0^{\mathrm{a}}$ & $3.0^{\mathrm{a}}$ & $3.1^{\mathrm{a}}$ & $3.6^{\mathrm{a}}$ & 15.2 \\
Moisture (\%) & $76.3^{\mathrm{a}}$ & $75.1^{\mathrm{a}}$ & $74.0^{\mathrm{a}}$ & $73.8^{\mathrm{a}}$ & 12.1 \\
Cholesterol (mg.100g $\left.{ }^{-1}\right)$ & $22.5^{\mathrm{c}}$ & $18.8^{\mathrm{d}}$ & $32.1^{\mathrm{a}}$ & $28.1^{\mathrm{b}}$ & 7.6 \\
Total caloric value $\left({\left.\mathrm{kcal} .100 \mathrm{~g}^{-1}\right)}^{101.3^{\mathrm{c}}}\right.$ & $87.2^{\mathrm{d}}$ & $163.4^{\mathrm{a}}$ & $139.5^{\mathrm{b}}$ & 9.4 \\
\hline
\end{tabular}

$\mathrm{CV}$ : coefficient of variation. Means in the same row, followed by different lowercase letters, are significantly different $(\mathrm{p}<0.05)$ by Tukey's test. Treatment $1=0 \%$ bacon and $0 \%$ Textured Soybean Protein (TSP); Treatment $2=0 \%$ bacon and 3.5\% TSP; Treatment $3=10 \%$ bacon and $0 \%$ TSP; Treatment $4=10 \%$ bacon and $3.5 \%$ TSP.

The samples in treatment 3 had the highest lipid and cholesterol levels due to the addition of bacon. Treatment 2 had the lowest fat level since it did not have bacon in its composition and the meat was partially replaced with TSP (Table 5).

Hoffman and Fisher (2001), studying ostrich meat from birds of different age, observed an average lipid level of $1.95 \%$, which was very close to that observed in treatment 1 , prepared without bacon and TSP. Bani et al. (2007), also studying 100\% pure ostrich meat, observed an average of $2.80 \%$ lipids, which is higher than that observed in treatment 1 . In the present study, however, the muscle studied was not identified (Table 5).

Hautrive et al. (2008) observed an average lipid level of $0.45 \%$ in ostrich meat hamburgers, which is lower than that found in treatment 2. Siqueira et al. (2001) observed averages of 2.1 to $2.6 \%$ for lipid levels in beef hamburgers using TSP and modified starch. Tavares et al. (2007) observed an average of $3.59 \%$ for lipid level in rabbit meat hamburgers, which is close to the value observed in treatment 4 .

In order for a product to be labeled as lean in the United States, it should contain less than $10 \%$ fat or less than $5 \%$ to be categorized as extra-lean (ARISSETO, 2003). Thus, all four formulations showed fat levels below $5 \%$, and therefore can be classified as extra lean burgers, even with the addition of bacon.

All studied formulations are in accordance with the Identity and Quality Technical Regulation (BRASIL, 2000), which establishes a maximum level of $15 \%$ for protein and $23 \%$ for fat, confirming the nutritional advantages of this type of meat.
Treatment 3 showed the highest levels of cholesterol differing significantly from the others due to the added bacon in its formulation; treatment 1 had the lowest levels. Arboitte et al. (2004), studying the Longissimus dorsi muscle of cattle, observed cholesterol levels of 48.23 to $56.46 \mathrm{mg} .100 \mathrm{~g} \mathrm{~g}^{-1}$, which are higher than those observed in all four treatments. Prado (2000), studying lamb meat, observed cholesterol levels of 65.23 to $76.90 \mathrm{mg} .100 \mathrm{~g}^{-1}$, also higher than those observed in the different treatments. As such, all treatments, even after bacon addition, show low cholesterol levels (Table 5).

Treatment 3 showed the highest caloric level, but it was lower than that observed by Torres et al. (2000) in beef strip loin, averaging $192 \mathrm{kcal} .100 \mathrm{~g}^{-1}$. The same researchers observed an average of $156 \mathrm{kcal} .100 \mathrm{~g}^{-1}$ in chicken drumstick, which is close to the value found in treatment 3 , and $100 \mathrm{kcal} 100 \mathrm{~g}^{-1}$ in turkey breast, very close to that observed for treatment 1 (Table 5).

\section{Conclusions}

The results obtained in this study indicate that all hamburger formulations prepared with ostrich meat had good acceptance by potential consumers, as demonstrated by the high level of acceptance and above-average scores for juiciness, flavor, and tenderness.

According to U.S. regulations, all formulations can be classified as extra-lean hamburgers, and they are also in accordance with Brazil's Identity and Quality Technical Regulation.

All formulations showed low levels of cholesterol and calories, even the hamburger made from $10 \%$ bacon and $3.5 \%$ TSP, which received the highest acceptance scores from the panelists.

\section{References}

ANZALDÚA-MORALEZ, A. La evaluación sensorial de los alimentos em la teoría y la práctica. Zaragoza: Editorial Acribia S. A., 1994. 220 p.

ARBOITTE, M. Z. et al. Composição física da carcaça, qualidade da carne e conteúdo de colesterol no músculo Longissimus dorsi de novilhos 5/8 Nelore 3/8 Charolês terminados em confinamento e abatidos em diferentes estágios de maturidade. Revista Brasileira de Zootecnia, v. 33, n. 4, p. 1110-1115, 2004.

ARISSETO, A. P. Avaliação da qualidade global do hambúrguer tipo calabresa com reduzidos teores de nitrito. 2003. 145 f. Dissertação (Mestre em Engenharia de Alimentos)-Universidade Estadual de Campinas, Campinas, 2003.

ASSOCIATION OF OFFICIAL AND AGRICULTURAL CHEMISTRY - AOAC. Official Methods and Recommend Practice of the American Oil Chemist's. 16. ed. AOAC, 1999. 1025 p.

BAGGIO, S.; BRAGAGNOLO, N. Validação da metodologia para determinação simultânea, por CLAE, de colesterol e óxido de colesterol em carne de peru. In: CONGRESSO BRASILEIRO DE QUALIDADE, 17., 2000, Fortaleza. Anais... Fortaleza, 2000. p. 23-25.

BANI, F. A. et al. Qualidade lipídica da carne de avestruz. Revista Nacional da Carne, n. 361, 2007. 
BRASIL. Conselho Nacional de Saúde. Resolução nº 196, de 10 de outubro de 1996. Estabelece os requisitos para realização de pesquisa clínica de produtos para saúde utilizando seres humanos. Diário Oficial da República Federativa do Brasil, Brasília, DF, 10 out. 1996. Disponível em: <http://e-legis.anvisa.gov.br/leisref/ public/showAct.php?id=663>. Acesso em: 22 maio 2009.

BRASIL. Ministério da Saúde. Agência Nacional e Vigilância Sanitária. Instrução Normativa no 20/2000, de 31 de julho de 2000. Regulamento Técnico de Identidade e Qualidade do Hambúrguer. Diário Oficial da República Federativa do Brasil, Brasília, DF, ago. 2000. Disponível em: <http://www.agricultura.gov.br $>$. Acesso em: 16 jun. 2009.

FALVELA, C. V. Carne de avestruz. Revista Nutrição Brasil, v. 3, n. 1, p. 51-54, 2004.

FERNÁNDEZ-LOPEZ, J. et al. Quality characteristics of ostrich (Struthio camelus) burgers. Meat Science, v. 73, n. 2, p. 295-303, 2006. PMid:22062301. http://dx.doi.org/10.1016/j.meatsci.2005.12.011

FOLCH, J.; LESS, M.; STANLEY, S. A. A simple Method for the Isolation and Purification of Total Lipids from Animal Tissues. Journal Biological Chemistry, v. 226, p. 497, 1957. PMid:13428781.

HAUTRIVE, T. P. et al. Análise físico-química e sensorial de hambúrguer elaborado com carne de avestruz. Ciência e Tecnologia de Alimentos, v. 28, p. 95-101, 2008. Suplemento.

HOFFMAN, L. C.; FISHER, P. P. Comparison of meat quality characteristics between young and old ostriches. Meat Science, v. 59, n. 3, p. 335-337, 2001. http://dx.doi.org/10.1016/S03091740(01)00055-9

LUCHINI, L.; COSTA, M. A hora é a do avestruz. A lavoura, ano 100, n. 624, p. 17-28, 1998.

PRADO, O. V. Qualidade da carne de cordeiros Santa Inês e Bergamácia abatidos com diferentes pesos. 2000. $109 \mathrm{f}$. Dissertação (Mestrado em Zootecnia)-Universidade Federal de Lavras, Lavras, 2000.

SÁ, E. M. F. A influência da água nas propriedades da carne- Parte II. Revista Nacional da Carne, n. 325, 2004.

SEABRA, L. M. J. et al. Fécula de mandioca e farinha de aveia como substitutos de gordura na formulação de hambúrguer de carne ovina. Ciência e Tecnologia de Alimentos, v. 22, n. 3, p. 244-248, 2002.

SIQUEIRA, P. B. et al. Desenvolvimento e Aceitação de Hambúrguer com Baixo Teor de Gordura. Foods Ingredients, n. 14, p. 74-77, 2001.

STATISTICAL ANALISYS SYSTEM INSTITUTE - SAS SAS/STAT user's guide. versão 8. Cary: Instituto SAS, 1999.

TAVARES, R. S. et al. Processamento e aceitação sensorial de hambúrguer de coelho (Ortytolagus curnicullus). Ciência e Tecnologia de Alimentos, v. 27, n. 3, p. 633-636, 2007. http://dx.doi. org/10.1590/S0101-20612007000300031

TORRES, E. A. F. S. et al. Composição centesimal e valor calórico de alimentos de origem animal. Ciência e Tecnologia de Alimentos, v. 20 , n. 2 , p. $145-150,2000$. http://dx.doi.org/10.1590/S010120612000000200003 